\title{
Questes
}

vestes Revue pluridisciplinaire d'études médiévales

\section{La ville folle dans la Faula de Peire Cardenal}

\section{Pierre Levron}

\section{OpenEdition}

\section{Journals}

\section{Édition électronique}

URL : http://journals.openedition.org/questes/2339

DOI : 10.4000/questes.2339

ISSN : 2109-9472

\section{Éditeur}

Les Amis de Questes

\section{Édition imprimée}

Date de publication : 15 mars 2003

Pagination : 11-13

ISSN : 2102-7188

\section{Référence électronique}

Pierre Levron, «La ville folle dans la Faula de Peire Cardenal », Questes [En ligne], 3 | 2003, mis en ligne le 01 janvier 2014, consulté le 19 septembre 2020. URL : http://journals.openedition.org/questes/2339 ; DOI : https://doi.org/10.4000/questes.2339

Ce document a été généré automatiquement le 19 septembre 2020.

(c) Association des amis de «Questes » 


\title{
La ville folle dans la Faula de Peire Cardenal
}

\author{
Pierre Levron
}

NOTE DE L'ÉDITEUR

Cet article n'a pas encore fait l'objet d'une autorisation de publication.

INDEX

Keywords : noise, city, madness, wisdom, melancholy, lunacy

Mots-clés : bruit, ville, folie, sagesse, mélancolie, délire 